\title{
DEVELOPMENT OF ȘUKŪK IN THE STATE OF KUWAIT, ITS CHALLENGES AND PROSPECTS
}

\author{
Waleed S. A. S. Alowaiyesh ${ }^{1}$ \\ Mohamad Taqiuddin Mohamed ${ }^{2}$ \\ Mohd Shahid Mohd Noh ${ }^{3}$
}

\begin{abstract}
Sukūk emerged in the last two decades as a noteworthy contender for conventional bonds. Their wider appeal for Muslim populations around the world led to more issuers preferring to issuing sukūk over conventional bonds. This is the case for most countries in the Islamic World, but not Kuwait, despite it being a world-renowned pioneer and hub for innovation and creativity in Islamic Finance and Shariah-compliant capital markets. This study examines the legal and regulatory framework for șukük in the State of Kuwait after giving a brief history of its development. Through qualitative analysis of news sources, country reports, and academic papers, this study attempts to identify the major challenges and hurdles facing the development of șukuk despite the illustrious track record of the Islamic Finance industry in
\end{abstract}

1 Ph.D Candidate, Department of Shariah and Economics, Academy of Islamic Studies, University of Malaya, 50603 Kuala Lumpur, Malaysia. alowaiyesh@ gmail.com

2 Senior Lecturer, Department of Shariah and Economics, Academy of Islamic Studies, University of Malaya, 50603 Kuala Lumpur, Malaysia. m.taqiuddin@, um.edu.my

3 Senior Lecturer, Department of Shariah and Economics, Academy of Islamic Studies, University of Malaya, 50603 Kuala Lumpur, Malaysia.shahid82@ um.edu.my 


\begin{abstract}
Kuwait. As per the study, the most notable challenges and hurdles are in relation to the benchmark yield curve, public awareness, and listing of șukuk. The study concludes by suggesting possible solutions which all require a higher level of coordination between government entities and relevant stakeholders.
\end{abstract}

Keywords: șukūk, Kuwait, development, capital markets, history, Islamic Finance

\title{
INTRODUCTION
}

In May 2005, Kuwait witnessed the issuance of the first $s u k \bar{u} k^{4}$ for a local company. It was the USD 100 million issue for The Commercial Real Estate Company. It was not a surprise that the issuance was oversubscribed by $133 \%,{ }^{5}$ as it came at a time of significant growth in investment activity, mainly in Shariah-compliant assets, with such assets being suitable for most types of investors, whether seeking investment in conventional or "Islamic" financial products. It is also worth noting that due to the lack of a comprehensive legal framework for the issuance of $s u k \bar{u} k$ in Kuwait, all șukūk issuances by Kuwaiti obligors or originators where done overseas; i.e. with Special Purpose Companies ("SPC") incorporated in other jurisdictions, such as the Kingdom of Bahrain and later on in Ireland and the United Arab Emirates. This first $s u k \bar{u} k$ was followed by several issuances in the next few months until it came to a complete halt in the year 2008 because of the Global Financial Crisis. One of the results of which was when The Investment Dar Company, a Kuwaiti Islamic investment company, declared on May 12, 2009 its failure to pay the biannual return on its USD 100 million $s u k \bar{u} k$; making it the first șuku $k$ default in the Gulf region. ${ }^{6}$

$4 \quad S u k \bar{u} k$ is the Arabic name and is derived from the word 'șakk' for the singular and 'şukūk' for the plural one. The term is used to refer to a legal instrument, check and deed. In classical practice, șukūk was used as papers representing financial obligations originating from trade and other commercial activities. However, $s u k \bar{u} k$ as applied in the capital markets pertains to the process of securitization and is generally defined as an Islamic bond. See Kamil, W.A.R., 'Introduction to Sukuk', Malaysian Sukuk Market Handbook (Kuala Lumpur: RAM Rating Services Berhad, 2008), 21-49.

5 See the official website of the Islamic Interbank Money Market (IIMM) of Bank Negara Malaysia (BNM), http://iimm.bnm.gov.my/index. php?ch=18\&pg=69\&ac=38\&tpl_id=63, accessed on 18 August 2019.

6 Van Wijnbergen, Sweder \& Sajjad Zaheer, 'Sukuk defaults: On Distress Resolution in Islamic Finance,' Tinbergen Institute Discussion Paper 13-087/VI/DSF57 (2013): 12-13. 
The return to sukuk issuances only came about when in November, 2015, the Capital Markets Authority of Kuwait ("CMA") released a completely-revised set of executive bylaws of the CMA Law (Law No. 7 of 2010 Regarding the Establishment of the Capital Markets Authority and Regulating Securities Activities and its Amendments) ${ }^{7}$ which included regulations that governed all matters relating to șukuk in Kuwait, whether private or public. Although the Kuwaiti capital markets witnessed a spur in șukük issuances after the introduction of these regulations, ${ }^{8}$ issuers still choose foreign markets for the incorporation of the $s u k \bar{u} k$ 's SPC. ${ }^{9}$

\section{ȘUKŪK: A BRIEF HISTORY}

Sukūk first appeared in Malaysia in the year 1990 in a corporate issuance by Shell MDS Bhd, and Malaysia continued to lead the way in șukuk issuances worldwide, with $86.8 \%$ of all issuances from 1995 to 2015 (Malaysian Institute of Accountants, 2012). ${ }^{10}$ However, Bahrain led the way for the first sovereign sukūk issuance through the Central Bank of Bahrain (then known as the Bahrain Monetary Authority), establishing its international șuku $k$ programme in 2001. ${ }^{11}$

Kuwait, on the other hand, had its first șukūk issuance for a Kuwaiti company in May 2005. It was a USD 100 million issue of ijārah șukūk (leasing bond) for Bahrain-based Commercial Real Estate șukūk Company arranged in support of its growing real-estate development projects in Kuwait and the region. The $s u k \bar{u} k$ has been structured as lease-to-own Islamic Shariah compliant securities with a five-year term maturing in 2010 and offering a semi-annual return on the leasing bond of 125 basis points over the US dollar and six months Libor. This sukūk was underwritten by Kuwait Finance House (Kuwait), Boubyan

7 See the official website of the Capital Markets Authority of Kuwait, https://www. cma.gov.kw/en/web/cma/cma-board-releases/-/cmaboardreleases/detail/352508, accessed on 18 August 2019.

8 See the official website of Kuwait News Agency (KUNA), 'Capital Markets Authority: We approved the issuance of bonds worth 4 billion dollars since 2015,' https://www.kuna.net.kw/ArticleDetails.aspx?id=2581451\&language=ar\#, published on 14 December 2016, accessed on 20 August 2019.

9 This fact is confirmed by reviewing all the șukuk issuances in Kuwait which were approved by the CMA, with none establishing a Kuwaiti SPC as the issuer for the șukūk structure.

10 Klein, Paul-Olivier \& Laurent Weill, 'Why do Companies Issue Sukuk?,' Review of Financial Economics, vol. 31 (2016): 26-33.

11 Simon Archer \& Rifaat Ahmed Abdel Karim, Islamic Capital Markets and Products: Managing Capital and Liquidity Requirements Under Basel III (New Jersey: John Wiley \& Sons, 2017), 11. 
Bank (Kuwait), in addition to Deutsche Bank, Emirates Islamic Bank, Gulf Investment Corp (Kuwait), Kuwait Financial Centre, Liquidity Management Centre, Bank Muscat International, Arab Islamic Bank (Palestine) and Arab Insurance Group (Bahrain). ${ }^{12}$ Despite the challenging market conditions, arrangers and structuring advisers, Bahrain-based Liquidity Management Centre, Kuwait Finance House and Kuwait Financial Centre, announced on May 19, 2010 that the USD 100 million Commercial Real Estate șukūk has been successfully settled and paid for on its maturity date. ${ }^{13}$

In comparison, the two șukūk issuances for The Investment Dar Company (TID) in October 2005 (USD 100 million) and September 2006 (USD 150 million $)^{14}$ were not as successful. The first 5-year musharakah (co-ownership) $s u k \bar{u} k$ was issued by TID with the collaboration of ABC Islamic Bank (Bahrain) in 2005. It offered 6-month LIBOR ${ }^{15}$ plus $2 \%$ annual, whereas the $2006 s u k u \bar{k}$ issue promised LIBOR plus 1.25 percent for the first 3 years and LIBOR plus 1.75 percent for the rest of the time period, distributed semi-annually. The sukūk issued in 2005 was registered on the Bahraini Stock Exchange while the 2006 șukūk issue was registered in Dubai International Financial Exchanges. Both the șukūk issues were structured as musharakah. ${ }^{16}$ By May 2009, TID declared its failure to pay biannual return on its USD 100 million $s u k \bar{u} k$; making it the first $s u k \bar{u} k$ default in the Gulf region. Shortly after, TID

12 See the official website of the Islamic Interbank Money Market (IIMM) of Bank Negara Malaysia (BNM), http://iimm.bnm.gov.my/index. $\mathrm{php} ? \mathrm{ch}=18 \& \mathrm{pg}=69 \& \mathrm{ac}=38 \& \mathrm{tpl} \mathrm{id}=63$, accessed on 18 August 2019. Original

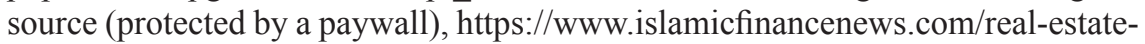
sukuk-oversubscribed.html

13 See TradeArabia Business News Information website, ' $\$ 100 \mathrm{~m}$ real estate sukuk a success,' http://www.tradearabia.com/news/BANK_180058.html, published on 19 May 2010, accessed on 20 September 2019.

14 See the website of Euromoney, 'Kuwait: Investment Dar leans on sukuk,' https:// www.euromoney.com/article/b1321y66phhrcf/kuwait-investment-dar-leans-onsukuk, published on 28 September 2006, accessed on 6 April 2020.

15 The London Interbank Offered Rate (LIBOR) is a benchmark interest rate at which major global banks lend to one another in the international interbank market for short-term loans.

16 Rafisah Mat Radzi \& Amir Shaharuddin, 'The Idealization of Risk-Profit Sharing in Partnership-Based Sukuk (Islamic Bonds): Why Sukuk Are Experiencing Default?' International Review of Management and Business Research, vol. 7 (2018): 633-645. 
defaulted on the second $s u k \bar{u} k$ as well, entered into a restructuring process, and demanded a standstill on all its debt for a temporary period. ${ }^{17}$

Clearly, the Global Financial Crisis ("GFC") of the year 2008 had a significant influence on the issuance of all types of securities, including suku $u$. What aggravated the matter even further was the lack of a comprehensive legal framework for șukuk in Kuwait. Therefore, and in the aftermath of the GFC, the Kuwaiti legislator issued Law No. 7 of 2010 Regarding the Establishment of the Capital Markets Authority and Regulating Securities Activities on February 21,2010 . The introduction of such law ushered the beginning of a new era in capital markets regulation after decades of supervision by the Central Bank of Kuwait. This included the establishment of a rival regulatory authority that would complement the enhance the existing regulatory framework. ${ }^{18}$

The developments in the legal framework did not stop at this, as the year 2012 witnessed the issuance of the completely revamped "Companies Law", ${ }^{19}$ which gave the CMA a mandate to regulate and supervise all matters relating to debt securities (namely, bonds and $s u k \bar{u} k$ ) issued in Kuwait. The CMA therefore commenced work on the development of a comprehensive framework in the following year in collaboration with an internationally recognized consultant. ${ }^{20}$ In November 2015, the CMA issued a completely revised set of executive bylaws of the CMA Law which were divided into 16 thematic modules, covering all areas of supervision and regulation of the capital markets (including șuk $\bar{k}$ ) under the umbrella of the CMA Law. ${ }^{21}$ Once these regulations came into force, a few months later the CMA approved the issuance of the first șuku $k$ for a Kuwaiti company under the new regime; a USD

17 Van Wijnbergen, Sweder \& Sajjad Zaheer, 'Sukuk defaults: On Distress Resolution in Islamic Finance,' 13.

18 See the official website of the Capital Markets Authority of Kuwait, Specifically the, 'Explanatory Memorandum (2010)', https://www.cma.gov.kw/en/web/cma/ law, accessed on 21 September 2019.

19 Sattout and Fadel, 'The new Companies Law - a step towards encouraging investments in Kuwait,' https://www.iflr1000.com/NewsAndAnalysis/The-newCompanies-Law-a-step-towards-encouraging-investments-in-Kuwait/Index/28, accessed on 5 October 2019.

20 See the website of Al-Watan Newspaper, http://alwatan.kuwait.tt/articledetails.asp $\mathrm{x} ? \mathrm{id}=396876 \&$ yearquarter $=20144$, published on 4 November 2014 , accessed on 5 October 2019.

21 Press release on the occasion of the issuance of the new executive bylaws (Resolution No. 72 of 2015). See the official website of the Capital Markets Authority of Kuwait, https://www.cma.gov.kw/en/web/cma/cma-board-releases/-/ cmaboardreleases/detail/369176\#, accessed on 7 October 2019. 
250 million perpetual șukūk to fulfill Boubyan Bank’s Tier 1 capital adequacy requirements as per the instructions of the Central Bank of Kuwait. ${ }^{22}$ Several $s u k \bar{u} k$ issuances followed, the latest being in September 2019 for Warba Bank. ${ }^{23}$

\section{THE CURRENT LEGAL AND REGULATORY FRAMEWORK FOR ȘUKŪK}

The CMA Law as amended in April 2015, includes a few main provisions enabling the issuance of $s u k \bar{u} k$ in Kuwait, mainly in the following articles: ${ }^{24}$

Article (1): Which includes the definitions of the main legal terms of the CMA Law including the definition of "Security: Any instrument - in any legal form - that evidences ownership of a share in a financial transaction and that is negotiable pursuant to a license from the Authority, such as: ... c) Loans; bonds; sukukk; and other instruments that can be converted to shares in the capital of a company d) All public debt instruments that are tradable and issued by the various government entities or public institutions and authorities..." and other important terms such as: "Dealing in Securities", "Investment Advisor", "Custodian", "Subscription Agent", "Initial Public Offering”, "Private Placement”, "Credit Rating Agency”.

Article (5): "The Authority shall carry out all the work necessary to achieve its goals, pursuant to this Law, and in particular the following:

$1-\ldots$

8 - Set up rules to regulate Dealing in Securities and the transfer of ownership.

22 See the website of Kuwait Times Newspaper, 'Boubyan Bank's sukuk issuance oversubscribed, reaches \$1.3bn,' https://news.kuwaittimes.net/website/boubyanbanks-sukuk-issuance-oversubscribed-reaches-1-3bn/, published on 10 May 2016, accessed on 7 October 2019.

23 See the website of Mubasher.info, 'CMA nods to Warba Bank's USD 500m sukuk prospectus,' https://english.mubasher.info/news/3529112/CMA-nods-to-WarbaBank-s-500m-sukuk-prospectus/, published on 11 September 2019, accessed on 15 December 2019.

24 See the official website of the Capital Markets Authority of Kuwait, https://www. cma.gov.kw/en/web/cma/law, accessed on 19 October 2019. 


\section{9 - Issue rules to regulate special purpose companies which issue Securities, without being limited to the provisions provided for in the Companies Law."}

Additionally, Article (150 bis) provides for exemptions from the prescribed tax on profits arising from the disposal of Securities listed on the Exchange, as well as exempting their returns, bonds, șukuk and other similar Securities, regardless of the Issuer, whereby this exemption is allowed for those Securities, whether the Issuer was a listed Kuwaiti or non-Kuwaiti company. The inclusion of this article was intended to encourage investors in Securities activities and companies to apply for listing and to motivate them to do so, thus becoming one of the factors urging and encouraging investment and trading in the Kuwaiti market. However, in a virtually tax-free environment, the exemption set forth in the law may only be beneficial to foreign investors, as local entities are not subject to any taxation in the State of Kuwait. ${ }^{25}$

The amendment of the CMA Law in April 2015 stipulated that the CMA should issue the revised executive bylaws within six months from the release of this amendment of the CMA Law. ${ }^{26}$ Accordingly, and before the end of the year 2015, the CMA completed one of the largest legislative projects in the history of the State of Kuwait. The new set of bylaws included over 1600 articles over 16 modules, covering all areas of capital markets regulation. ${ }^{27}$ As for $s u k \bar{u} k$, the relevant modules are: ${ }^{28}$

\section{Module 1 (Glossary):}

This module includes the definition of all the significant terms found in the modules of the executive bylaws, including the definition for "șukuk", "Issuer", "Obligor", "Originator", "Asset-based" and "Asset-backed" șukuk, "SPC", "Financial Trust", "Trustee”, "Representative", "Government șukūk”, etc.

25 See the website of Oxford Business Group, 'Kuwait's recent tax changes and regulations,' https://oxfordbusinessgroup.com/overview/what-comes-next-seriesnew-laws-pave-way-investment, accessed on 7 July 2020.

26 Article 152 of the CMA Law.

27 See the website of Alrai Media Newspaper, published on 22 September 2015 (issue 13231 - A0), https://www.alraimedia.com/Home/Details?id=6694c66de2f4-4b0e-8369-abf9b3743177, accessed on 7 October 2019.

28 See the official website of the Capital Markets Authority of Kuwait, https://www. cma.gov.kw/en/web/cma/-bylaw-documents, accessed on 19 October 2019. 


\section{Module 11 (Dealing in Securities):}

This module includes the majority of the regulatory framework for $s u k \bar{u} k$, starting from the issuance and subscription to termination. It includes special provisions regarding credit rating, special purpose companies (i.e. SPC), shariah opinion, șukūk structures, government $s u k \bar{u} k$, perpetual șukukk, and others.

\section{Module 12 (Listing Rules):}

This module includes listing and trading requirements of equities and debt instruments such as bonds and șukuk. The regulations set-forth in this module are complemented by the "Boursa Kuwait Rulebook" and "OTC Trading Rules", ${ }^{29}$ which are approved by the CMA for implementation by Boursa Kuwait Company, the only licensed securities exchange in the State of Kuwait.

Additionally, the CMA has signed a Memorandum of Understanding ("MoU") with the Central Bank of Kuwait ("CBK") on January 17, 2018 to organize the cooperation between the two parties (i.e. CMA and CBK) in shared areas of supervision, one of which is the area of public debt instruments, including $s u k \bar{u} k$ issued for the government of the State of Kuwait. ${ }^{30}$

The șukukk regulation framework was designed as per IOSCO's “Guidelines to Emerging Market Regulators" 31 with the following main components, as stipulated in Module 11 (Dealing in Securities) of the CMA executive bylaws: ${ }^{32}$

\section{Licensing Criteria}

All șukūk issuances and/or offering in the State of Kuwait shall require prior approval by the CMA as per provisions set-forth in Module 11 of the CMA executive bylaws.

29 See the official website of Boursa Kuwait, https://www.boursakuwait.com.kw/ regulations/rules-and-bulletins/rulebook, accessed on 7 October 2019.

30 See the official website of the Capital Markets Authority of Kuwait, https://www. cma.gov.kw/en/web/cma/moui, accessed on 19 October 2019.

31 IOSCO (2009). Guidelines to emerging market regulators regarding requirements for minimum entry and continuous risk-based supervision of market intermediaries [online. Available: http://www.iosco.org/library/pubdocs/pdf/IOSCOPD314.pdf, accessed on 19 October 2019], OSCO Library, Public documents.

32 See the official website of the Capital Markets Authority of Kuwait, https://www. cma.gov.kw/en/web/cma/-bylaw-documents, accessed on 19 October 2019. 


\section{Governance Rules}

Module 11 of the CMA executive bylaws provides for provisions to regulate the issuance of Special Purpose Companies ("SPC") which will perform two main roles: (i) act as Trustee; and (ii) issue șukūk. Accordingly, Module 11 includes provisions for "Trust Documents" to allow for the protection of the rights of $s u k \bar{u} k$ holders. Additionally, the same Module 11 requires that every șukuk issuance setup a "șukūk holders Association" to protect the common interests of the $s u k \bar{u} k$ holders.

\section{Investment Rules}

The transactions forming the basis of every șukuk shall be in accordance with the $s u k \bar{u} k$ structure that is predefined in the sukūk Subscription Prospectus. More importantly, Module 11 also stipulates that the șukuk structure shall be reviewed by a qualified Sharia advisor to confirm its compliance with Islamic Shariah.

\section{External Audit}

As per Module 11, the CMA and the sukūk holders' Representative shall receive a copy of the audited annual report and periodic financial statements of the sukūk's Obligor and its Issuer (i.e. the SPC), as well as any Shariah compliance reports.

\section{Shariah Approval and Audit}

The provisions of Module 11 require that the sukūk's Prospectus document includes a statement confirming that the $s u k \bar{u} k$ issuance is compliant with Shariah. Additionally, the same Module 11 stipulates that a certified External Shariah Auditing Office shall be appointed to audit the șukūk periodically and continuously until redemption. It is worthwhile noting that External Shariah Auditing Offices are registered at the CMA under the registration regime prescribed in Module 5 (Securities Activities and Registered Persons) of the CMA executive bylaws.

\section{Disclosure Requirements}

Listed sukūk would be subject to the provisions set-forth in Modules 10 (Disclosure and Transparency) and Module 12 (Listing Rules) of the CMA 
executive bylaws in addition to any other disclosure requirements stipulated by the Boursa Kuwait Rulebooks. Non-listed șukūk however, as per this Module 11 , are required to disclose any material information to the CMA and șukuk holders, if such information is not public, including information related to any new fundamental developments in the field of its business or which can be expected to have a material influence on the obligations arising from the suk $u \bar{u}$.

\section{Minimum Capital and Reserves}

The CMA executive bylaws do not impose any minimum capital or reserves requirements at the moment as part of the sukūk regulation framework. However, sukūk issued for banks and financing companies are subject to approval by the Central Bank of Kuwait, which includes specific capital adequacy requirements for such entities. It is noteworthy that the CMA has launched a project to prepare regulations of capital adequacy standard for non-banking financial institutions with a view to establishing an effective monitoring system in accordance with international standards. ${ }^{33}$

\section{Winding Up Provisions}

Article 11-73 of Module 11 covers all matters in relation to Liquidation and Bankruptcy for $s u k \bar{u} k$, whether planned or forced. While Article 11-87 of the same module covers the expiry of the Trust Document and Articles 7-40 to 7-42 provide for the liquidation and winding up rules for SPCs.

\section{MAJOR CHALLENGES AND HURDLES}

As per the current regulatory framework, the issuance of $s u k \bar{u} k$ requires the prior approval of the CMA, as long as any of the main parties involved is under the supervision of the CMA; namely the Issuer, Obligor, Originator, and Subscription Agent. This means that even an issuance by a special purpose company (i.e. SPV) incorporated outside of Kuwait would require the prior approval of the CMA if the Obligor, for example, is a Kuwaiti entity. And so far, no sukūk denominated in Kuwaiti Dinars were issued under the current framework since its release in the year 2015; i.e. because all of the sukūk

33 See the website of Kuwait Times Newspaper, 'CMA project to set capital adequacy standards,' https://news.kuwaittimes.net/website/cma-project-to-set-capital-adeq uacy-standards/, published on 18 February 2019, accessed on 19 October 2019. 
approved by the $\mathrm{CMA}^{34}$ were issued by special purpose companies incorporated outside of Kuwait. Hence, despite the readiness of the regulatory framework, the sukuk industry in Kuwait may still face some challenges in the course of its development. The following are some of the most notable challenges and hurdles in the development of the șukūk industry in Kuwait:

\section{Benchmark Yield Curve}

The yield curve is a plot of yields on securities of different maturities at a particular point in time. ${ }^{35}$ Studying the yield curve assists both lenders and borrowers in making correct expectations about the direction and quantum of change in the yield and therefore the price of bonds that facilitate investors' investment decisions. Furthermore, an examination of bond types and their classifications shows similarities between șukūk and conventional bonds. ${ }^{36}$

For this, it is important to note that the sovereign suku $\bar{u}$ is generally the first inroad into Shariah compliant funding in the capital market, enabling the creation of reference prices over time, to which private sector entities can benchmark their fundraising activities. Governments have for the most part, remained the most active issuers in the history of the global șukuk market with sovereign issuances accounting for more than 80 percent of the global șukūk issuances. ${ }^{37}$ Therefore, a push towards issuance of $s u k \bar{u} k$ by the Kuwaiti government and its related entities in essential to establish a benchmark yield curve for corporate issuers of $s u k \bar{u} k$ in Kuwait.

34 Till the date of this article in June 2019.

35 Awaludin, Fadhlee \& Mansur Masih, 'Sukuk Pricing Dynamics - Factors Influencing Yield Curve of the Malaysian Sukuk,' (2015): 4. MPRA Paper 66355, University Library of Munich, Germany. https://ideas.repec.org/p/pra/ mprapa/66355.html, accessed on 4 July 2020.

36 Adesina-Uthman \& Ganiyat Adejoke, Term Structure of Profit Rates of Sukuk: MATLAB Stochastic Simulation (Cambridge: Cambridge Scholars Publishing, 2015): 1 .

37 Awaludin, Fadhlee \& Mansur Masih, 'Sukuk Pricing Dynamics - Factors Influencing Yield Curve of the Malaysian Sukuk,' (2015): 8. MPRA Paper 66355, University Library of Munich, Germany. https://ideas.repec.org/p/pra/ mprapa/66355.html, accessed on 4 July 2020. 


\section{Awareness}

Șukuk as a new and complex instrument (in comparison to conventional bonds) is not well known by investors yet. This would not be the case if more $s u k \bar{u} k$ were issued, and then listed. The lack of which would lead to price distortions and high yield over conventional bonds. These negative consequences would deter potential issuers from issuing șukük. Hence, the reasons and consequences of a weak secondary market can get into a vicious circle. Additionally, lack of awareness about șukukk and its benefits deters potential issuers from issuing $s u k \bar{u} k .^{38}$ Thus, increasing awareness could lead to breaking that vicious circle.

As per Article (3) Clause No. 7 of the CMA Law, one of the main objectives of the CMA is to "enhance public awareness of Securities activities and of the benefits, risks and obligations arising from investments in Securities and encourage their development." ${ }^{39}$; especially that the șukuk legal framework was introduced only four years ago in November 2015 with the issuance of the new executive bylaws by Resolution No. 72 of $2015 .^{40}$

Furthermore, the government of Kuwait only issued sovereign bonds, with no issuances of sovereign $s u k \bar{u} k$ till this date. The government's interest in issuing șukuk however is evident through its numerous attempts to issue the required pieces of legislation for the issuance of sovereign $s u k \bar{u} k$ in addition to the creation of the "Debt Management Department" at the Ministry of Finance. By examining these government initiatives, we observed the following:

a) In September, 2019 the Kuwaiti Council of Ministers approved a bill for government șukuk, which aims to complete the legislative and regulatory framework for the Islamic Finance Industry in Kuwait. ${ }^{41}$ In comparison with the regulatory framework set-forth by the CMA Law, and in particular the provisions of Module 11 (Dealing in Securities) of the CMA executive bylaws, this draft bill fails to introduce the necessary provisions that would

38 Ulusoy, Ahmet \& E. L. A. Mehmet, 'Secondary Market of Sukuk: An Overview,' Uluslararası Íslam Ekonomisi ve Finansı Araştırmaları Dergisi, vol. 4, no. 2 (2018): 17-32.

39 See the official website of the Capital Markets Authority of Kuwait, https://www. cma.gov.kw/en/web/cma/law, accessed on 26 October 2019.

40 See the official website of the Capital Markets Authority of Kuwait, https://www. cma.gov.kw/en/web/cma/cma-board-releases/-/cmaboardreleases/detail/369176\#, accessed on 26 October 2019.

41 See the official website of Kuwait News Agency (KUNA), 'Kuwait Cabinet holds weekly meeting', https://www.kuna.net.kw/ArticleDetails.aspx?id=2820141, published on 23 September 2019, accessed on 2 November 2019. 
complete the legislative framework in addition to lacking some of the most important elements required for issuance of $s u k \bar{u} k$, most notably: ${ }^{42}$

i) Lack of provisions that would regulate the ownership or beneficial ownership of public assets as defined by Decree Law No. 15 of 1980 regarding properties owned by the State of Kuwait. This is essential, as the current legal framework might pose a legal challenge to the securitization of government assets.

ii) Lack of provisions that would regulate the creation of a Financial Trust to protect the rights of $s u k \bar{u} k$ holders. While this was clearly covered in Module 11 (Dealing in Securities) of the CMA executive bylaws (Chapter 11).

iii) Incorrect role of the Special Purpose Company (i.e. Special Purpose Vehicle) as the prescribed role in the draft bill resembles the role of a Collective Investment Scheme.

Overall, the draft bill in several of its provisions is attempting to regulate aspects of $s u k \bar{u} k$ that are already regulated by the legal framework setforth by the CMA Law and its executive bylaws.

b) In January, 2019 five members of Kuwait's National Assembly submitted a sukukk bill; an initiative that did not grab the headlines as parliament had more immediate and critical issues to deal with at the time. This bill sets the rules for the issuance of $s u k \bar{u} k$ by the government, public bodies and stateowned enterprises, joint stock companies, banks, as well as international and regional financial institutions. ${ }^{43}$ Thus, this bill is attempting to replace the legal framework set-forth by the CMA Law, and in particular the provisions of Module 11 (Dealing in Securities) of the CMA executive bylaws. From examining the draft bill that is available on the website of Kuwait National

42 The analysis of the draft bill was based on the academic paper. See Hammad Mustafa Azab, 'Legal Regulation of Islamic Sukuk and its Importance in Activating their Role in Achieving Economic and Social Development: A Study in Kuwaiti and Egyptian Law,' Kuwait International Law School Journal, vol. 4/1 (2019): 268-279. Also, see the website of Aljarida Newspaper, published on 1 October 2019, https://www.aljarida.com/articles/1569859312182939100/, accessed on 2 November 2019.

43 Article from official website of multimedia journalist, Marc Roussot, 'Kuwaiti Sukuk law and issuance resurface,' https://marcroussot.com/2019/03/13/kuwaitisukuk-law-and-issuance-resurface/, published on 13 March 2019, accessed on 3 November 2019. 
Assembly, ${ }^{44}$ we see that it fails to introduce the necessary provisions that would complete the legislative framework in addition to lacking some of the most important elements required for issuance of șukuk , most notably the lack of provisions that would regulate the ownership or beneficial ownership of public assets as defined by Decree Law No. 15 of 1980 regarding properties owned by the State of Kuwait; which is necessary to allow for the securitization of government assets.

What is more troublesome is that this draft includes several provisions to regulate aspects of $s u k \bar{u} k$ that are already regulated by the legal framework set-forth by the CMA Law and its executive bylaws.

c) Kuwait has been the most recent country among the $\mathrm{GCC}^{45}$ nations to setup a debt management department under the Ministry of Finance, and Moody's noted that this measure is a key reform that would help the country in the long-run. ${ }^{46}$ The Debt Management Department was established in April 2016 with a mandate to set financing policies for the State of Kuwait, perform risk assessment and explore alternatives to issuance of sovereign bonds, in addition to the coordination with relevant government entities to issue sovereign bonds locally and internationally. ${ }^{47}$

As per the Article IV consultation report issued in March 2019 by a staff team of the International Monetary Fund (IMF), which included the Financial System Stability Assessment (FSSA) of Kuwait, "further institutional and legal reforms are needed to enhance debt management" by the State of Kuwait. The report concluded that such reforms require that the authorities secure the Parliament's authorization to resume borrowing by issuance of

44 See the website of El Dostor at the official website of Kuwait National Assembly,

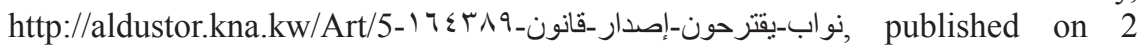
January 2019, accessed on 3 November 2019.

45 "GCC" stands for the Gulf Cooperation Council which refers to the countries of The Cooperation Council for the Arab States of the Gulf, namely: Bahrain, Kuwait, Oman, Qatar, Saudi Arabia, and the United Arab Emirates (UAE).

46 See the Moody's, 'Rating Action: Moody's changes outlook on Government of Kuwait's Aa2 rating to stable from negative; affirms rating', https://www.moodys. $\mathrm{com} /$ research/Moodys-changes-outlook-on-Government-of-Kuwaits-Aa2-ratingto--PR_366560\#, published on 26 May 2017, accessed on 13 November 2019.

47 See the official website of the Ministry of Finance - Debt Management Department page https://mof.gov.kw/DMD/DMD.aspx, accessed on 18 November 2019. 
sovereign bonds and șukük to help build a long-term yield curve in dinars and expand the investor base. ${ }^{48}$

Thus, the efforts of the Debt Management Department could only be realized when the parliament authorizes the Ministry of Finance to resume borrowing. Nevertheless, and despite these efforts, the State Audit Bureau of Kuwait recorded in its reports several observations regarding the Debt Management Department, most notably the observations regarding its contractual arrangement with Tri International Consulting Group ("TICG"). ${ }^{49}$ Some of the observations were (as recorded in the local Kuwaiti newspapers):

i) The contract with TICG was renewed in $2018^{50}$ and again in $2019^{51}$ despite not completing one of its two main deliverables, recruitment of local human resources to join the Debt Management Department, since the beginning of its mandate in 2016. ${ }^{52}$

ii) Unjustified increase in the contract value upon renewal with TICG in 2018 in addition to not disclosing fee structure and whether the compensation included in kind benefits. ${ }^{53}$

48 See the official website of the International Monetary Fund (IMF), 'Kuwait: 2019 Article IV Consultation; Press Release; Staff Report; and Statement by the Executive Director for Kuwait', https://www.imf.org/en/Publications/CR/ Issues/2019/04/02/Kuwait-2019-Article-IV-Consultation-Press-Release-StaffReport-and-Statement-by-the-46729, published on 2 April 2019, accessed on 18 November 2019.

49 TICG is a Kuwait-based management consulting firm founded as a joint venture between the Kuwait Investment Authority (KIA), Oliver Wyman, and the Kuwait Fund for Arab Economic Development (KFAED). Refer to TICG's official website for further info, https://www.ticg.com.kw/, accessed on 27 November 2019.

50 See the website of Alqabas Newspaper, https://alqabas.com/article/657073ديوان_المحاسبة_r, published on 14 April 2019, accessed on 27 November 2019.

51 See the website of Alqabas Newspaper, https://alqabas.com/article/5719172مليار-دينار -سحبت_من_الاحتياطي_العام_في_ع_سنوات-267, published on 22 October 2019, accessed on 27 November 2019.

52 See the website of Alqabas Newspaper, https://alqabas.com/article/312240--نخفاض

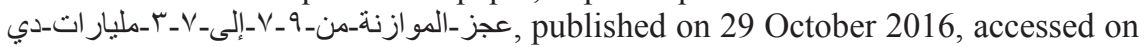
27 November 2019.

53 See the website of Alanba Newspaper, https://www.alanba.com.kw/ar/economynews/822789/01-04-2018-ديوان-المحاسبة-يطالب-بتعديل-الاحتياطي_العام/2018 published on 1 April 2019, accessed on 27 November 2019. 
iii) No significant progress was made regarding the issuance of $s u k u \bar{k}$ legislation and not completing the inventory count of the government's real-estate assets, despite the passing of over three years since the start of this mandate. ${ }^{54}$

\section{Listing}

Șukuk issuers often see securities listing as key to liquidity, access to more investors and greater visibility to global institutional investors. ${ }^{55}$ Accordingly, as per a presentation given at the 17 th Edition of AAOIFI's ${ }^{56}$ Annual Shari'ah Conference, ${ }^{57}$ of the issued 207 USD-denominated $s u k u k$, 195 are listed in one securities exchange or more $(94.2 \%) .{ }^{58}$ This fact confirms the prevalence of listed suku $u k$ notwithstanding the lack of trading volumes of $s u k \bar{u} k$ as the majority of $s u k \bar{u} k$ are held till maturity. ${ }^{59}$

Thus, the provisions of Chapter 4 of Module 12 (Listing Rules) of the CMA executive bylaws ${ }^{60}$ laid out a comprehensive framework for the listing of $s u k \bar{u} k$ (in addition to bonds) in Boursa Kuwait Securities Exchange. Additionally,

54 See the website of Alqabas Newspaper, https://alqabas.com/article/657073ديو ان_المحاسبة_ro published on 14 April 2019, accessed on 27 November 2019.

55 Deloitte's Islamic Finance Knowledge Center (IFKC) in collaboration with the International Shari'ah Research Academy for Islamic Finance (ISRA), 'Sukuk in Focus: The Necessity for Global Common Practices,' Deloitte's Islamic Finance Insights Series, https://www2.deloitte.com/kw/en/pages/financial-services/ articles/sukuk-focus.html, accessed on 30 November 2019.

56 AAOIFI is the Accounting and Auditing Organization for Islamic Financial Institutions, a Bahrain based not-for-profit organization that was established to maintain and promote Shariah standards for Islamic financial institutions, participants and the overall industry.

57 Hatem Ghouma, 'Sukuk Listing in Global Financial Markets and Compatibility of Listing Requirements with Shari'ah Structures' (Paper presented, AAOIFI $17^{\text {th }}$ Annual Shari'ah Boards Conference, Kingdom of Bahrain, 8 April 2019).

58 Ghouma H., 'The Listing of Sukuk: Goals and Consequences,' Global Islamic Economics Magazine, vol. 93 (2020): 67-78.

59 Najeeb, Syed Faiq, Obiyathulla Bacha \& Mansur Masih, 'Does a held-to-maturity Strategy Impede Effective Portfolio Diversification for Islamic Bond (Sukuk) Portfolios? A Multi-Scale Continuous Wavelet Correlation Analysis,' Emerging Markets Finance and Trade, vol. 53, no. 10 (2017): 2377-2393.

60 See the official website of the Capital Markets Authority of Kuwait, https://www. cma.gov.kw/en/web/cma/-bylaw-documents, accessed on 30 November 2019. 
"Boursa Kuwait Rulebook" and "OTC Trading Rules"61 provided for the relevant rules on the side of the securities exchange. Hence, as Boursa Kuwait is a "Licensed Person" and thus, these rules were approved by the relevant authority (i.e. the CMA) prior to their publication. ${ }^{62}$

Despite the completeness of the legal framework, the CMA is yet to complete the necessary market infrastructure to allow for the listing of $s u k \bar{u} k$. This is outlined in a presentation given by the Head of Markets Regulation Department at the CMA during a workshop for the students of the College of Business Administration at Kuwait University, ${ }^{63}$ regarding "Market Development and Upgrade within Indices" (workshop held 1 May 2019). As per that presentation, the key objectives of the CMA's "Market Development Program" are: (a) Upgrade clearing \& settlement practices to be in line with international standards; (b) Support the introduction of more sophisticated financial instruments and investment products; and other key objectives. The first objective (a) is a prerequisite for the latter objective (b). And thus, the introduction of $s u k \bar{u} k$ is planned in Phase 4 of the Market Development Program, which is expected to start in the year 2020. It is worth mentioning that this gradual approach to market development is because the CMA is targeting compliance with the Principles for Financial-Markets Infrastructures ("PFMI") which are published by the Committee on Payment and Settlement Systems ("CPSS"), which is comprised of the International Organization of Securities Commissions ("IOSCO") and the Bank for International Settlement ("BIS"). ${ }^{64}$

\section{THE PROSPECT FOR ȘUKŪK IN KUWAIT}

After going through a brief history of the development of șukuk and in more details regarding the legal and supervisory framework as stipulated by the CMA Law and its executive bylaws in addition to other relevant regulations,

${ }_{61}$ See the official website of the Boursa Kuwait, https://www.boursakuwait.com. kw/regulations/rules-and-bulletins/rulebook, accessed on 30 November 2019.

62 As per Article 1-5 of (Rules and Regulations of an Exchange) Module 4 (Securities Exchanges and Clearing Agencies) of the CMA executive bylaws.

63 See the official website of the Capital Markets Authority of Kuwait, https://www. cma.gov.kw/en/web/cma/awarenessevents/-/cmageneric/page_4, accessed on 30 November 2019.

64 See the official website of the Capital Markets Authority of Kuwait, awareness brochure "Capital Markets Development in the State of Kuwait", dated 26 March 2017, https://www.cma.gov.kw/en/web/cma/awarenesspublications/-/ cmageneric/page_5, accessed on 30 November 2019. 
this study attempted to highlight the major challenges facing the development of the $s u k \bar{u} k$ industry in the capital markets of Kuwait. The main challenges as summarized by this study are in relation to the (1) Yield Curve; (2) Awareness; and (3) Listing of sukūk. Progress made in any of these three areas could benefit the other two as they are interlinked and not mutually exclusive. For example, facilitating the listing of $s u k \bar{u} k$ in Boursa Kuwait, could encourage local issuers to issue Kuwaiti Dinar-based șukuk (i.e. Obligors to establish a Kuwaiti SPV to issue local sukūk). Likewise, reaching out to government or government-owned entities to increase awareness about șukūk could lead to the issuance of sovereign $s u k \bar{u} k$ which would contribute to building a yield curve for Kuwaiti Dinar-based șukūk.

This study showed that the capital markets regulator in the State of Kuwait has put in place a comprehensive legal framework for the issuance of $s u k \bar{u} k$. The current state of no issuances of Kuwaiti Dinar-based $s u k \bar{u} k$ indicates that this framework has yet to be tested. This is why the government of Kuwait (whether directly or indirectly through government-owned entities) should step in and take the first steps of issuing truly local șukuk and listing them in the local securities exchange, i.e. Boursa Kuwait.

From the progress made and the evident efforts of several major stakeholders, namely the Capital Markets Authority, Ministry of Finance, and Central Bank of Kuwait, a Kuwaiti Dinar-based șukūk is eminent. The need to issue sukūk is further supported by the following:

a) Increasing public demand for universal Shariah-compliance across the government body and its public facilities, most importantly in financial matters involving Kuwaiti citizens, such as the national pension fund (i.e. Public Institute for Social Security in Kuwait or "PIFSS"), ${ }^{65}$ or the recent public placement of two government-owned entities (which in this context is considered a privatization of government assets in accordance with the relevant laws and regulations): "Shamal Az Zour Al Oula K.S.C"66 and "Boursa Kuwait Securities Exchange Company K.P.S.C.". ${ }^{67}$

65 See the website of Aljarida Newspaper, https://www.aljarida.com/ articles/1570988685498302000/, published on 14 October 2019, accessed on 20 December 2019.

66 See the official website of Kuwait News Agency (KUNA), '127,000 people subscribe to Shamal Azzour Al-Oula Co.-authority', https://www.kuna.net.kw/ ArticleDetails.aspx ?id $=2838907$ \&language $=$ en\#, published on 30 November 2019, accessed on 20 December 2019.

67 Bloomberg, 'Kuwait Bourse IPO More Than 8.5 Times Oversubscribed,' https:// www.bloomberg.com/news/articles/2019-12-02/kuwait-bourse-ipo-more-than-85-times-oversubscribed, published on 2 December 2019, accessed on 20 December 2019. 
b) Rising pressure on budgetary policy as ever-increasing salaries for government employees are being challenged by volatile oil prices, with export of crude oil being the main source of income for the government of Kuwait. ${ }^{68}$ The fiscal budget is facing an increasing deficit which is urging the government to consider short term solutions with risky long term consequences. ${ }^{69}$

For the latter, the government of Kuwait repeatedly attempted to reform or at least curb the increase in the salaries but with not much success. ${ }^{70} \mathrm{We}$ conclude from the analysis done in this study that if the challenges highlighted were overcome (i.e. the challenges facing the development of $s u k \bar{u} k$ in the capital markets of Kuwait), the State of Kuwait could resolve several issues as follows:

a) Increase capital expenditure and spending for the country's infrastructure maintenance and development through the issuance of $s u k \bar{u} k$ for project finance. This would reduce the competition between the different items of the fiscal budget, and save the government of Kuwait from resorting to medium and long term borrowing to fulfil its immediate operational expenditure requirements (mainly in the form of payment of salaries and government subsidies).

It is worth noting that in September 207 the law allowing the Ministry of Finance to issue debt expired, bringing new issuances to a halt. Less than a year after its first debt issuance, Kuwait's parliament approved a bill allowing the government to raise the borrowing ceiling from USD 30 billion to USD 83 billion and sell sovereign bonds out to 30 years. $^{71}$

68 See the website of Reuters, 'Kuwait to boost spending, eyes oil price at USD 55-65/ bbl', https://www.reuters.com/article/kuwait-economy-budget/update-1-kuwaitto-boost-spending-eyes-oil-price-at-55-65-bbl-idUSL8N1ZL3CD, published on 21 January 2019, accessed on 20 December 2019.

69 See the website of Kuwait Times Newspaper, 'Fitch: Kuwait political disputes to delay debt issuance, reform,' https://news.kuwaittimes.net/website/fitch-kuwaitpolitical-disputes-to-delay-debt-issuance-reform/, published on 9 December 2019, accessed on 20 December 2019.

70 Refer to Article IV consultation report issued in April 2019 by a staff team of the International Monetary Fund (IMF).

71 See the website of Global Finance Magazine, 'Kuwait: Strong and Stable, Seeking New Pizzazz', https://www.gfmag.com/magazine/february-2018/kuwait-strongand-stable-seeking-new-pizzazz, published on 15 February 2018, accessed on 20 December 2019. 
b) Meet public demand for Shariah-compliant alternatives. For this, $s u k u \bar{k}$ could be issued to finance the maintenance and development of incomegenerating government assets operated by government-related entities such as:

i) Kuwait Petroleum Corporation (and its subsidiaries).

ii) Credit Bank (responsible for issuance of home ownership loans).

iii) Companies established by Kuwait Authority for Partnership Projects (KAPP), such as the abovementioned Shamal Az Zour Al Oula K.S.C.

iv) Kuwait Airways (the national carrier of the State of Kuwait).

v) Public Utilities Management Company (specialized in property management, including rental and leasing of real estate).

vi) Kuwait Public Transport Company (runs local and international bus transportation services).

vii) Touristic Enterprises Company (owns and operates amusement and recreational parks; manages entertainment and tourism facilities in Kuwait).

viii) Livestock Transport \& Trading Company (produces frozen and packed meat products, fertilizers and animal feed; owns and operates cattle farms, meat slaughterhouses, meat stores and marine fleets for cattle transportation).

c) Fulfil the objectives of the CMA Law, namely objective number 2 as stipulated in Article 3 of the CMA Law: "Grow the capital markets, and diversify and develop investment instruments thereof in accordance with best international practice." It is noteworthy that this clause was added to the CMA Law in the amendment of 2015 to serve the Kuwaiti financial market to be in line with the developments affecting this sector. ${ }^{72}$ The benefits derived from the growth of $s u k \bar{u} k$ in the capital markets are numerous; some of which are:

i) Offer an alternative investment opportunity for local and foreign investors in the capital markets of the State of Kuwait.

ii) Reduce the concentration on equities by complementing them with debt instruments (i.e. $s u k \bar{u} k$ ).

72 See the official website of the Capital Markets Authority of Kuwait, Specifically the "Explanatory Memorandum (2010)", https://www.cma.gov.kw/en/web/cma/ law, accessed on 20 December 2019. 
iii) Increase diversity and depth of the capital markets leading to a more resilient financial sector.

iv) Offer an alternative mode of financing for both the public and private sectors.

v) Contribute to the realization of the 2035 Amiri Vision to transform Kuwait into an international financial hub and trade centre.

\section{CONCLUSION}

Finally, as presented by this paper, the challenges facing șukūk development are intertwined with a high degree of interdependence. Additionally, the mandate (and authority) to act upon any of those challenges is not exclusive to one party, but includes several parties both from the private and public sectors. Therefore, coordination and collaboration are necessary to overcome the hurdles delaying the development of șukūk in the capital markets of Kuwait. In a similar manner, the IMF highlighted in its Kuwait Country Report the importance of this coordination by stating that "The authorities should also establish a formal coordination mechanism between the agencies overseeing the financial sector" ${ }^{73}$ Also, as noted earlier, coordination and collaboration is not limited within the public sector, but also requires the involvement of the private sector, most notably the two main entities in the capital markets: the clearing agency (i.e. Kuwait Clearing Company K.S.C., abbreviated as "KCC") and the securities exchange (i.e. Boursa Kuwait Securities Exchange Company K.P.S.C., abbreviated as "Boursa"). ${ }^{74}$ The benefits of such collaboration are evidenced by the recent successful upgrade to "Emerging Markets Status" by FTSE Russell and most recently by MSCI. ${ }^{75}$

73 IMF Country Report No. 19/96 "Kuwait: Financial System Stability Assessment", issued in April 2019.

74 See Abdullah Alharoun, 'Kuwait,' The International Capital Markets Review, https://thelawreviews.co.uk/edition/the-international-capital-markets-reviewedition-9/1211063/kuwait, accessed on 20 December 2019.

75 The Kuwaiti Minister of Commerce and Industry Khaled Al-Roudhan noted in a news conference held on 19 December 2019 that "The CMA has made the achievement in cooperation with other national authorities, namely the Central Bank of Kuwait (CBK), the Ministry of Commerce and Industry, Kuwait Clearing Company and the Kuwaiti stock market". See the Kuwait News Agency (KUNA), 'USD 3 billion forecast inflow into Kuwait bourse-official', https://www.kuna.net. kw/ArticleDetails.aspx?id=2843229, published on 19 December 2019, accessed on 20 December 2019. 
In this effect, we would like to refer to a comment by the Head of Investment Banking at NBK Capital during the fourth annual Kuwait Debt Capital Market Conference: "With the prospects of recurring sovereign issuances by the State becoming lukewarm, perhaps it is time to consider taking prominent Kuwaiti government related entities to market as an alternative to a purely sovereign yield curve". ${ }^{76}$ This in fact is the approach of most governments in the other GCC countries; the following are examples of some of these issuances:

1. Kingdom of Bahrain: Financed the development of Bahrain International Airport in the year 2004 with a 40 million Bahraini Dinars șuku k. ${ }^{77}$

2. State of Qatar: Financed several of its hallmark projects with the issuance of $s u k \bar{u} k$, starting with its first issuance in the year $2003 .^{78}$

3. United Arab Emirates (UAE): The UAE commenced its șukūk issuances with USD 100 million to finance the National Central Cooling Company PJSC (Tabreed), ${ }^{79}$ a leading district cooling company which is a subsidiary of Mubadala Investment Company. ${ }^{80}$

4. Sultanate of Oman: The government of Oman issued its first sovereign $s ̧ u k \bar{u} k$ in 2015, a 200 million rial (USD 520 million), five-year șukūk issue with an ijārah structure. Furthermore, this sovereign șukūk was listed on the Muscat Securities Market, providing a benchmark which encourages private Omani companies to issue $s u k \bar{u} k{ }^{81}$

76 See the official website of Watani Investment Company (NBK Capital), 'NBK Capital Sponsors The Gulf Bonds and Sukuk Association's Kuwait Debt Capital Markets Conference', https://nbkcapital.com/2019/nbk-capital-sponsors-gulfbonds-sukuk-associations-kuwait-debt-capital-markets-conference/, published on 25 March 2019, accessed on 20 December 2019.

77 Wedderburn-Day \& A. Roger, 'Sovereign Sukuk: Adaptation and Innovation,' Law and Contemporary Problems, vol. 73, no. 4 (2010): 325-333.

78 Silva, Nash, 'Sukuk Guide: An Essential Introduction to the Islamic Bond Market,' HSBC Global Research (2015): 35.

79 Alvi, I. A., A. R. Mohammed, G. Z. Khan, U. M. Nasser, B. Naseer \& M. S. Khan, 'Sukuk Report, A Comprehensive Study of The International Sukuk Market,' The International Islamic Financial Market (2010): 1-75.

80 Mubadala Investment Company is a wholly owned investment vehicle of the government of Abu Dhabi in the UAE.

81 See the website of Reuters, 'Oman's first sovereign sukuk issue attracts strong orders', https://www.reuters.com/article/oman-sukuk/omans-first-sovereignsukuk-issue-attracts-strong-orders-idUSL8N12P07720151025, published on 25 October 2015, accessed on 22 December 2019. 
5. Kingdom of Saudi Arabia: Saudi Arabia issued its first governmentbacked sukuk in the year 2012 for its aviation agency, at 15 billion riyals, or USD 4 billion. The șukuk, guaranteed by the Saudi Ministry of Finance, was oversubscribed three times, and the Saudi General Authority for Civil Aviation will use the proceeds to finance the expansion of King Abdulaziz International Airport in Jeddah. ${ }^{82}$

Thus, we conclude that in order to realize șukūk's full potential, a higher level of coordination is needed between the government entities and relevant stakeholders to achieve the necessary alignment towards the common goal of a more active and resilient capital markets; a source of alternative financing that is both, Shariah-compliant and commercially viable.

\section{REFERENCES}

Adesina-Uthman \& Ganiyat Adejoke, Term Structure of Profit Rates of Sukuk: MATLAB Stochastic Simulation (Cambridge: Cambridge Scholars Publishing, 2015).

Alvi, I. A., A. R. Mohammed, G. Z. Khan, U. M. Nasser, B. Naseer \& M. S. Khan, 'Sukuk Report, A Comprehensive Study of The International Sukuk Market,' The International Islamic Financial Market (2010): $1-75$.

Simon Archer \& Rifaat Ahmed Abdel Karim, Islamic Capital Markets and Products: Managing Capital and Liquidity Requirements Under Basel III (New Jersey: John Wiley \& Sons, 2017).

Awaludin, Fadhlee \& Mansur Masih, 'Sukuk Pricing Dynamics - Factors Influencing Yield Curve of the Malaysian Sukuk,' (2015): 4,8. MPRA Paper 66355, University Library of Munich, Germany. https://ideas. repec.org/p/pra/mprapa/66355.html, accessed on 4 July 2020.

Ghouma H., 'The Listing of Sukuk: Goals and Consequences,' Global Islamic Economics Magazine, vol. 93 (2020): 67-78.

Hammad Mustafa Azab, 'Legal Regulation of Islamic Sukuk and its Importance in Activating their Role in Achieving Economic and Social Development: A Study in Kuwaiti and Egyptian Law,' Kuwait International Law School Journal, vol. 4/1 (2019): 268-279.

82 See the website of The New York Times, 'Saudi Arabia Issues Its First Sovereign Islamic Bond', https://www.nytimes.com/2012/01/26/world/middleeast/26ihtm26-saudi-sukuk.html, published on 25 January 2012, accessed on 21 December 2019. 
Hatem Ghouma, 'Sukuk Listing in Global Financial Markets and Compatibility of Listing Requirements with Shari'ah Structures' (Paper presented, AAOIFI 17th Annual Shari' ah Boards Conference, Kingdom of Bahrain, 8 April 2019).

Klein, Paul-Olivier \& Laurent Weill, 'Why do Companies Issue Sukuk?,' Review of Financial Economics, vol. 31 (2016): 26-33.

Bank Negara Malaysia, Malaysian Sukūk Market Handbook: Your Guide to the Malaysian Islamic Capital Market (Kuala Lumpur: Bank Negara Malaysia, 2008).

Rafisah Mat Radzi \& Amir Shaharuddin, 'The Idealization of Risk-Profit Sharing in Partnership-Based Sukuk (Islamic Bonds): Why Sukuk Are Experiencing Default?' International Review of Management and Business Research, vol. 7 (2018): 633-645.

Najeeb, Syed Faiq, Obiyathulla Bacha \& Mansur Masih, 'Does a heldto-maturity Strategy Impede Effective Portfolio Diversification for Islamic Bond (Sukuk) Portfolios? A Multi-Scale Continuous Wavelet Correlation Analysis,' Emerging Markets Finance and Trade, vol. 53, no. 10 (2017): 2377-2393.

Silva, Nash, 'Sukuk Guide: An Essential Introduction to the Islamic Bond Market,' HSBC Global Research (2015): 35.

Ulusoy, Ahmet \& E. L. A. Mehmet, 'Secondary Market of Sukuk: An Overview,' Uluslararası İslam Ekonomisi ve Finansı Araştırmaları Dergisi, vol. 4, no. 2 (2018): 17-32.

Van Wijnbergen, Sweder \& Sajjad Zaheer, 'Sukuk defaults: On Distress Resolution in Islamic Finance,' Tinbergen Institute Discussion Paper 13-087/VI/DSF57 (2013): 12-13.

Wedderburn-Day \& A. Roger, 'Sovereign Sukuk: Adaptation and Innovation,' Law and Contemporary Problems, vol. 73, no. 4 (2010): 325-333.

Deloitte's Islamic Finance Knowledge Center (IFKC) in collaboration with the International Shari'ah Research Academy for Islamic Finance (ISRA), 'Sukuk in Focus: The Necessity for Global Common Practices,' Deloitte's Islamic Finance Insights Series, https:/www2.deloitte.com/ $\mathrm{kw} / \mathrm{en} /$ pages/financial-services/articles/sukuk-focus.html, accessed on 30 November 2019.

Oxford Business Group, 'Kuwait's recent tax changes and regulations,' https:// oxfordbusinessgroup.com/overview/what-comes-next-series-new-lawspave-way-investment, accessed on 7 July 2020. 
Alanba Newspaper, 'ديوان المحاسبة بطالب بتعديل الاحتياطي العام,' https://www.

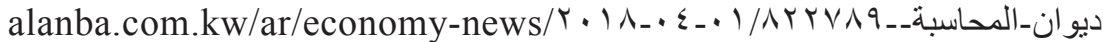
يطالب_بتعديل_الاحتياطي_العام November $r \cdot 19$.

Aljarida Newspaper, 'الحكومة تحيل إلى المجلس مشروع قانون الصكوك الحكومية, https:// www.aljarida.com/articles/1569859312182939100/, published on 1 October 2019, accessed on 2 November 2019.

Aljarida Newspaper, 'اتفاق حكومي نيابي على استمرار رسوم التأمينات, https://www. aljarida.com/articles/1570988685498302000/, published on 14 October 2019, accessed on 20 December 2019.

Alqabas Newspaper, 'ديوان المحاسبة: 2.15 مليار دينار انخفاض الاحتياطي العام في 9 أثنهر,'

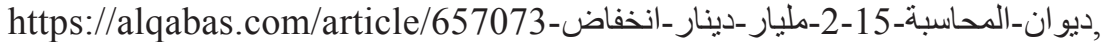
published on 14 April 2019, accessed on 27 November 2019.

Alqabas Newspaper, 'الاحتياطي العام ينزف 27 مليار دينار,' https://alqabas.com/

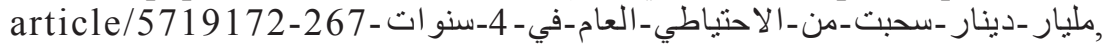
published on 22 October 2019, accessed on 27 November 2019.

Alqabas Newspaper, 'انخفاض عجز الموازنة من 9.7 إلى 7.3 مليار ات دينار', https://

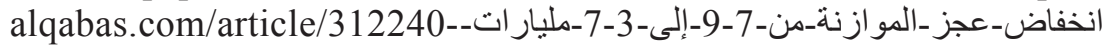
دي , published on 29 October 2016, accessed on 27 November 2019.

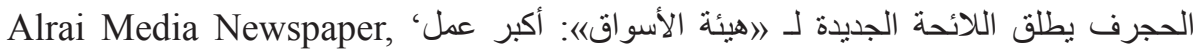
تشريعي وتتظيمي في ناريخ الكويت, https://www.alraimedia.com/Home/ Details?id=6694c66d-e2f4-4b0e-8369-abf9b3743177, published on 22 September 2015, accessed on 7 October 2019.

Al-Watan Newspaper, 'أسواق المال: القواعد المفصلة للأسهم الممتازة والصكوك... قريباً,' http://alwatan.kuwait.tt/articledetails.aspx?id=396876\&yearquart er=20144, published on 4 November 2014, accessed on 5 October 2019.

Bloomberg, 'Kuwait Bourse IPO More Than 8.5 Times Oversubscribed,' https://www.bloomberg.com/news/articles/2019-12-02/kuwait-bourseipo-more-than-8-5-times-oversubscribed, published on 2 December 2019, accessed on 20 December 2019.

Boursa Kuwait, 'Boursa Kuwait Rulebook,' https://www.boursakuwait.com. $\mathrm{kw} /$ regulations/rules-and-bulletins/rulebook, accessed on 30 November 2019.

Capital Markets Authority of Kuwait, awareness brochure 'Capital Markets Development in the State of Kuwait,' https://www.cma.gov.kw/en/ web/cma/awarenesspublications/-/cmageneric/page_5, published on 26 March 2017, accessed on 30 November 2019. 
Capital Markets Authority of Kuwait, 'Resolution No. (72) of 2015 the Issuance of the Executive Bylaws of Law No. 7 of 2010 Regarding the Establishment of the Capital Markets Authority and Regulating Securities Activities and its Amendments,' https://www.cma.gov.kw/ en/web/cma/cma-board-releases/-/cmaboardreleases/detail/352508, accessed on 18 August 2019.

Capital Markets Authority of Kuwait, 'Memoranda of Understanding (MoUs),' https://www.cma.gov.kw/en/web/cma/moui, accessed on 19 October 2019.

Capital Markets Authority of Kuwait, 'Speech of the Capital Markets Authority>s Chairman on the Occasion of the Issuance of the New Executive Bylaws,' https://www.cma.gov.kw/en/web/cma/cma-boardreleases/-/cmaboardreleases/detail/369176\#, accessed on 26 October 2019.

Capital Markets Authority of Kuwait, 'The Regulatory Requirements of “the Unlicensed" Listed Companies' Financial Statements,' https:// www.cma.gov.kw/en/web/cma/awarenessevents/-/cmageneric/page_4, accessed on 30 November 2019.

Capital Markets Authority of Kuwait, Specifically the 'Explanatory Memorandum (2010)', https://www.cma.gov.kw/en/web/cma/law, accessed on 20 December 2019.

Abdullah Alharoun, 'Kuwait,' The International Capital Markets Review, https://thelawreviews.co.uk/edition/the-international-capital-marketsreview-edition-9/1211063/kuwait, accessed on 20 December 2019.

El Dostor at the official website of Kuwait National Assembly, http://aldustor. kna.kw/Art/5-164389, published on 2 January 2019, accessed on 3 November 2019.

Euromoney, 'Kuwait: Investment Dar leans on sukuk,' https:/www.euromoney. com/article/b1321y66phhrcf/kuwait-investment-dar-leans-on-sukuk, published on 28 September 2006, accessed on 6 April 2020.

Global Finance Magazine, 'Kuwait: Strong and Stable, Seeking New Pizzazz', https://www.gfmag.com/magazine/february-2018/kuwait-strong-andstable-seeking-new-pizzazz, published on 15 February 2018, accessed on 20 December 2019.

International Monetary Fund Country Report No. 19/96 'Kuwait: Financial System Stability Assessment', issued in April 2019. 
International Monetary Fund (IMF), 'Kuwait: 2019 Article IV Consultation; Press Release; Staff Report; and Statement by the Executive Director for Kuwait', https://www.imf.org/en/Publications/CR/Issues/2019/04/02/ Kuwait-2019-Article-IV-Consultation-Press-Release-Staff-Report-andStatement-by-the-46729, published on 2 April 2019, accessed on 18 November 2019.

International Organization of Securities Commissions (IOSCO), 'Guidelines to Emerging Market Regulators Regarding Requirements for Minimum Entry and Continuous Risk-based Supervision of Market Intermediaries,' http://www.iosco.org/library/pubdocs/pdf/IOSCOPD314.pdf, accessed on 19 October 2019.

Islamic Interbank Money Market (IIMM) of Bank Negara Malaysia (BNM), 'Real estate Sukuk oversubscribed,' http://iimm.bnm.gov. my/index.php?ch $=18 \& p g=69 \& a c=38 \&$ tpl_id $=63$, accessed on 18 August 2019. Original source (protected by a paywall), https://www. islamicfinancenews.com/real-estate-sukuk-oversubscribed.html

Marc Roussot, 'Kuwaiti Sukuk law and issuance resurface,' https://marcroussot. com/2019/03/13/kuwaiti-sukuk-law-and-issuance-resurface/, published on 13 March 2019, accessed on 3 November 2019.

Kamil, W.A.R., 'Introduction to Sukuk', Malaysian Sukuk Market Handbook (Kuala Lumpur: RAM Rating Services Berhad, 2008).

Kuwait News Agency (KUNA), 'Capital Markets Authority: We approved the issuance of bonds worth 4 billion dollars since 2015,' https://www.kuna. net.kw/ArticleDetails.asp $\mathrm{x}$ ?id=2581451\&language $=$ ar\#, published on 14 December 2016, accessed on 20 August 2019.

Kuwait News Agency (KUNA), ' 127,000 people subscribe to Shamal Azzour Al-Oula Co.-authority’, https://www.kuna.net.kw/ArticleDetails. aspx?id=2838907\&language $=$ en\#, published on 30 November 2019, accessed on 20 December 2019.

Kuwait News Agency (KUNA), 'Kuwait Cabinet holds weekly meeting', https://www.kuna.net.kw/ArticleDetails.aspx?id=2820141, published on 23 September 2019, accessed on 2 November 2019.

Kuwait Times Newspaper, 'Boubyan Bank's sukuk issuance oversubscribed, reaches \$1.3bn,' https://news.kuwaittimes.net/website/boubyan-bankssukuk-issuance-oversubscribed-reaches-1-3bn/, published on 10 May 2016, accessed on 7 October 2019. 
Kuwait Times Newspaper, 'CMA project to set capital adequacy standards,' https://news.kuwaittimes.net/website/cma-project-to-set-capitaladequacy-standards/, published on 18 February 2019, accessed on 19 October 2019.

Kuwait Times Newspaper, 'Fitch: Kuwait political disputes to delay debt issuance, reform,' https://news.kuwaittimes.net/website/fitch-kuwaitpolitical-disputes-to-delay-debt-issuance-reform/, published on 9 December 2019, accessed on 20 December 2019.

Ministry of Finance - Debt Management Department page, https://mof.gov. kw/DMD/DMD.aspx, accessed on 18 November 2019.

Moody's, 'Rating Action: Moody's changes outlook on Government of Kuwait's Aa2 rating to stable from negative; affirms rating', https:// www.moodys.com/research/Moodys-changes-outlook-on-Governmentof-Kuwaits-Aa2-rating-to--PR_366560\#, published on 26 May 2017, accessed on 13 November $201 \overline{9}$.

Mubasher.info, 'CMA nods to Warba Bank's USD 500m sukuk prospectus', https://english.mubasher.info/news/3529112/CMA-nods-to-WarbaBank-s-500m-sukuk-prospectus/, published on 11 September 2019, accessed on 15 December 2019.

Kuwait News Agency (KUNA), 'USD 3 billion forecast inflow into Kuwait bourse-official', https:/www.kuna.net.kw/ArticleDetails. aspx?id=2843229, published on 19 December 2019, accessed on 20 December 2019.

Capital Markets Authority of Kuwait, https://www.cma.gov.kw/en/web/cma/ cma-board-releases/-/cmaboardreleases/detail/369176\#, accessed on 7 October 2019.

Reuters, 'Oman's first sovereign sukuk issue attracts strong orders', https:// www.reuters.com/article/oman-sukuk/omans-first-sovereign-sukukissue-attracts-strong-orders-idUSL8N12P07720151025, published on 25 October 2015, accessed on 22 December 2019.

Reuters, 'Kuwait to boost spending, eyes oil price at USD 55-65/bbl', https:// www.reuters.com/article/kuwait-economy-budget/update-1-kuwaitto-boost-spending-eyes-oil-price-at-55-65-bbl-idUSL8N1ZL3CD, published on 21 January 2019, accessed on 20 December 2019.

Sattout \& Fadel, 'The New Companies Law: A Step Towards Encouraging Investments in Kuwait,' https://www.iflr1000.com/NewsAndAnalysis/ The-new-Companies-Law-a-step-towards-encouraging-investments-inKuwait/Index/28, accessed on 5 October 2019. 
The New York Times, 'Saudi Arabia Issues Its First Sovereign Islamic Bond', https://www.nytimes.com/2012/01/26/world/middleeast/26ihtm26-saudi-sukuk.html, published on 25 January 2012, accessed on 21 December 2019.

TICG's official website, https://www.ticg.com.kw/, accessed on 27 November 2019.

TradeArabia Business News Information website, ' $\$ 100 \mathrm{~m}$ real estate sukuk a success,' http://www.tradearabia.com/news/BANK_180058.html, published on 19 May 2010, accessed on 20 September 2019.

Watani Investment Company (NBK Capital), 'NBK Capital Sponsors The Gulf Bonds and Sukuk Association's Kuwait Debt Capital Markets Conference', https://nbkcapital.com/2019/nbk-capital-sponsors-gulfbonds-sukuk-associations-kuwait-debt-capital-markets-conference/, published on 25 March 2019, accessed on 20 December 2019.

\section{Legislations}

Law No. 7 of 2010 Regarding the Establishment of the Capital Markets Authority and Regulating Securities Activities and its Executive Bylaws and their Amendments. 
Jurnal Syariah, Jil. 28, Bil. 2 (2020) 263-292 